\title{
CONSTRUCCIÓN SOCIAL DE LA ETNICIDAD: EGOY ALTER EN ATACAMA
}

\author{
Héctor Morales M. ${ }^{1}$
}

\section{* Introducción}

Resumen

Esta investigación se centra en el denominado pueblo "atacameño", en el cómo y cuándo fueron nombrados de esta manera. Desde esta perspectiva, los registros escritos de naturalistas, misioneros, administradores públicos y arqueólogos del s. XIX y principios del XX muestran conceptos y concepciones que hasta hoy determinan las lecturas de este pueblo de Atacama. Por lo tanto, la etnicidad en Atacama es examinada bajo dos fuentes fundamentales: relatos etnohistóricos y etnografías recogidas entre pobladores y líderes atacameños en los últimos años. Ambas fuentes entregan datos sobre una etnogénesis paradójica: la emergencia de un sujeto social, producto de un pacto entre el triunfador de la Guerra del Pacífico, Chile, y los grupos campesinos propietarios atacameños, los cuales, de hecho, se harán parte de

la campaña de integración y chilenización de la Atacama boliviana.

Palabras claves: identidad cultural - etnogénesis - etnopolítica - San Pedro de Atacama - atacameños.

This research focuses on the name of the "Aracamenian" people, on how and when they were appointed in this way. From this perspective, the written records of naturalists, missionaries, public administrators and archaeologists of the XIX and early XX Centuries display concepts and conceptions that even today determine the readings of this town of Atacama. Therefore, ethnicity in Atacama is examined under two main sources: ethnohistoric accounts and ethnographies collected between Atacama residents and leaders in recent years. Both sources of evidence give light on a paradoxical ethnogenesis: the emergence of a social subject: the result of a pact between the winner of the Pacific War (Chile) and Atacama ownerspeasant groups, who, in fact, will become part of the campaign of integration and "Chileanization" of the Bolivian Atacama.

Key words: cultural identity - ethnogenesis - ethnopolitics - San Pedro de Atacama - Atacamenians.

Recibido: marzo 2013. Aceptado: julio 2013.
La etnicidad atacameña se inserta en el campo de estudios multiculturales que en los últimos 30 años ha situado el concepto en un espacio reflexivo que permite comprender fenómenos asociados a los procesos de etnificación que se han observado en Chile y otros países latinoamericanos. Esto involucra tanto la construcción/ revitalización de identidades culturales originarias, como el despliegue de estrategias políticas frente a la sujeción y asimilación de la diferencia cultural a través de procesos de inclusión y exclusión por parte de la sociedad mayor.

Esa condición proyectada a través del tiempo, da expresión a una determinada dinámica socio y etnopolítica entre los distintos grupos existentes en Atacama. Ella adquirió dimensiones sociales y alcanzó expresiones racistas que siguen vigentes hasta hoy. Sin embargo, en los últimos 20 años, pese a la diversidad interna, los líderes atacameños se presentarán frente a otros grupos nacionales, como un cuerpo social homogéneo, situación que será estimulada desde la propia política de la diversidad cultural llevada a cabo por el Gobierno de Chile.

Lo étnico, como diferencia cultural ${ }^{2}$, se ha transformado en un reto conceptual y metodológico debido a la emergencia de nuevas identidades étnicas que han puesto en cuestión las antiguas unidades culturales. Es precisamente la aparición de nuevos grupos étnicos lo que ha permitido evaluar la condición sociocultural de este fenómeno.

1 Departamento de Antropología, Facultad de Ciencias Sociales, Universidad de Chile. Ignacio Carrera Pinto 1045, Nuñoa, Santiago, CHILE. Email: hmorales@u.uchile.cl 
En este artículo, se considera la hipótesis que en Atacama opera un sistema interétnico a manera de una estructura social que permite el intercambio simbólico, económico, social e incluso cultural entre diferentes grupos étnicos, a lo menos entre atacameños campesinos del oasis de San Pedro de Atacama, pastores de Puna denominados collas y grupos quechua asentados en la cuenca del Alto Loa. Por tanto, el propósito de este trabajo es caracterizar esta situación de génesis y relaciones entre los distintos grupos sociales de Atacama.

Respecto de la metodología de investigación, será eminentemente cualitativa; se reconstruirán discursos y agentes de etnización a través de las fuentes bibliográficas. Posteriormente, en el trabajo de campo, se recopilaron etnografías de los diversos grupos comprometidos en estos procesos. Los resultados de esta investigación dan cuenta de las diferencias entre los distintos grupos sociales y con ello, permiten contribuir a un mejor entendimiento de las dinámicas socioculturales en Atacama.

\section{* Nominaciones: Naturalistas, misioneros, MILITARES, FUNCIONARIOS Y ARQueÓlogos en ATACAMa}

Los diversos documentos evidencian la presencia de distintos actores que estamparon sus registros en textos y manuscritos que dan cuenta de las singularidades de las

\footnotetext{
2 Mientras en Europa lo "étnico" puede aludir a las antiguas nacionalidades imaginadas o inventadas que dieron origen a los modernos Estados nacionales (Anderson 1993; Zizek 1998, 2001; Hobsbawm 2002 [1983]), en América Latina alude a pueblos originarios, grupos descendientes directos de las primeras poblaciones que habitaron el continente. Pese a que la categoría de "indio" e "indígena" tiene sentidos múltiples, el concepto refiere a una condición histórica que emerge de la conquista hispánica y de su posterior proyección poscolonial en las repúblicas criollas (Abercrombie 1991, 2006; Albó 2000; Boccara 1999, 2002; Degregori y Portocarrero 2004; Díaz-Polanco 2006). Lo étnico se vincula, pues, a un esquema de dominación que se extiende desde el estigma de la identidad cultural degradada, al sometimiento político y la exclusión socioeconómica (Stavenhagen 2000, 2001; Hopenhayn 2005). La idea de grupos sociales responde a las cualidades socioeconómicas de productores agrícolas, ganaderos y pastores especializados insertos en el mercado regional. Por último, la referencia a grupos culturales tiene relación a marcadores religiosos, tecnológicos y organizacionales, entre otros (Bartolomé 1979, 2000, 2004).
}

poblaciones en Atacama, y es precisamente, la lengua como marcador cultural la que permitió establecer la diferencia y la singularidad ampliamente relatada en distintos períodos (D'Orbigny 1839; Philippi 1860; Moore 1877; Bertrand 1885; San Román 1896; Vaïsse 1896; Créqui-Monfort y Sénéchal 1904; Schuller 1908; Uhle 1912). sin embargo, existen otros tipos de marcadores culturales como la arquitectura, la alimentación, los cultivos, la religión, que en general, responden más bien a una matriz regional andina.

En este apartado nos concentraremos en la nominación del pueblo atacameño, cómo y cuándo fueron nombrados por sus vecinos, y por ellos mismos reconociendo el s. XIX como el momento en que aparecen conceptos y concepciones que hasta hoy determinarán las lecturas de este pueblo de Atacama.

Fue el naturalista D'Orbigny (1839), quien terminó con el "panquichuismo" andino, considerando a los lipes o atacameños como eslabón entre los quechua y mapuche. En su obra evidencia la diferencia lingüística entre quechua, atacamas y mapuche. Aquí se termina con la creencia de que el quechua era una lengua generalizada a todos los pueblos de esta región andina. Esto se reafirma con posteriores descripciones escritas al respecto. Un dato histórico relevante es que en sus escritos denominó a estos pobladores como "Los Atacamas" (Schuller 1908: 8).

Cerca de 20 años después, otro naturalista, Philippi, viajó a petición del Gobierno de Chile a la antigua región de Atacama, que se extendía desde el río Copiapó hasta el puerto de Cobija. Indicó en 1853 que la lengua de Atacama era totalmente distinta a la de sus vecinos. Con cierta probabilidad, por primera vez, en términos formales, denomina a los habitantes de Atacama como atacameños. En adelante, los indígenas o indios de Atacama serán llamados atacameños. Confirmó además que la lengua de los atacameños es un "idioma particular, enteramente distinto del quechua y del aymara como del chileno" (Philippi 1860: 56), concordando así con D'Orbigny. Por lo anterior se atrevió a reunir un pequeño vocabulario de este idioma y a cotejar sus términos con el quechua, el aymara y el "chileno". Señaló que este idioma era hablado en esa época por una "población de tres a cuatro mil almas" (Philippi 1860: 56), y que son poquísimos los blancos residentes en sus pueblos "Toconao, Soncor, Socaire, 
Peine, Antofagasta de la Sierra y unos pequeños lugarcitos del cantón Chiu Chiu" (Philippi 1860: 56), lo que obviamente facilita la conservación de la lengua propia.

Según Philippi, el atacameño es por entonces mucho más hablado todavía en el área de San Pedro y los contornos del Salar de Atacama, y raramente ya en el área del Loa Superior. Esto podría deberse a dos factores: el mayor poblamiento de la zona de Atacama desde tiempos antiguos y el mayor tráfico regional por Chiu Chiu hacia la zona costera de Cobija, exponiéndolo a visitantes y migraciones fundamentalmente quechua. El autor afirma que la distribución geográfica de esta lengua fue mayor: "[...] se hablaba también en Chiu Chiu y Calama, pero actualmente lo ha subrogado el español en estos pueblos y solo personas muy anzianas entienden todavía la lengua de sus padres" (Philippi 1860: 56).

Aquí se tiene la comprobación notoria de lo que ocurría en Chiu Chiu: los ancianos aún lo hablan en 1853-1854 (época del viaje de Philippi), lo mismo que en Peine, con motivo del viaje de Mostny en 1949, un siglo después, quien escucha hablar la lengua kunza a unos pocos ancianos. ${ }^{3}$

Para Philippi, en esta época (1858) en toda la zona de Atacama imperó la lengua quechua de los incas. Turi, en el sector norte, y Catarpe junto al Pucara de Quitor, fueron baluartes del Inka y centros de control de la población atacameña y, por lo tanto, la lengua quechua fue ampliamente conocida en Atacama. Probablemente sus caciques la aprendieron conforme a la costumbre inca de enseñarla a los pueblos conquistados. Por eso, tal vez, el quechua se introdujo en el kunza, dejando en él muchísimos vocablos híbridos, lo que fue demostrado por (Lehnert 1981,1991), probablemente en base a Vaïsse, estudioso sacerdote políglota y cura de San Pedro de Atacama (Vaïse et al. 1896), que muestra que pese a la presencia quechua, que debió ser fuerte en la zona, no se impidió la conservación de la lengua de Atacama o kunza hasta casi mediados del s. XX (Mostny 1954).

Una década después de la expedición de Philippi, el viajero alemán Tschudi (1869), recorre toda la zona de Ata-

\footnotetext{
3 Resulta de sumo interés la precisión de Philippi de que esta lengua es hablada también "en Antofagasta en la costa a 300 kilómetros de San Pedro de Atacama" (1860: 56).
}

cama proponiendo que la "afiliación lingüística de los indígenas del desierto era una fracción refugiada en las escarpadas serranías del pueblo Calchaqui provincia de Salta, Catamarca y La Rioja" (Schuller 1908: 8). Otro aporte importante es el de Moore (1877), quien reafirma la particularidad del idioma y la cultura en Atacama.

En un pequeño artículo el ingeniero y geógrafo San Román, llama kunza a este idioma, que traducido al castellano significaría "nuestro". Este funcionario público del Gobierno de Chile, tipifica como "ingeniosa" la teoría de Tschudi, respecto de la pertenencia de los atacamas a la cultura Calchaquí, diciendo que "[...] no cabe duda que el kunza pertenece a la misma rama de que ha nacido el aimara, puquina, canchi o quichua" (San Román 1890).

Agrega Vaïsse, que las poblaciones ubicadas arriba de Atacama, en las serranías, eran llamadas lickan (hombres de arriba). De la misma manera, los habitantes de Socaire, según San Román, llamaban vaquit a quienes vivían en los pueblos de abajo.

Vaïsse menciona que:

“[...] lickan: El pueblo por excelencia. -Ese término designa exclusivamente a S. Pedro de Atacama. Para designar a otros lugares habitados, los atacameños empleaban Leri- De ahí podría deducirse que Lickan era el nombre de Atac. antes de la conquista.- Usase para designar toda la rejion atacameña, en el sentido de país, nación; pero se emplea entónces la forma siguiente: Lickana: rejion atacameña... Lickantacki: atacameño" (1896: 23).

Así, lickana significa región atacameña (Figura 1). Desde un análisis etimológico comparado, según Tschudi (1869) el vocablo atacama derivado de "p'atacama", significa "reunión de jefes". ${ }^{4}$ Otra posibilidad es la nominación propia de la lengua kunza, donde existe la palabra tecar, que significa frío, tener frío, tecama: tengo frío, donde se asocia la nominación a un factor climático. Finalmente atacameño será en idioma kunza, tecama (Schuller 1908: 8).

4 Puede que se haya dado el nombre al desierto, por los conquistadores incas antes de la llegada a Chile, o por los numerosos indios quechuas que acompañaron a Almagro, quien designó a San Pedro de Atacama como punto de reunión para las gentes, al regresar a Perú (Oviedo 1902 (1557). 


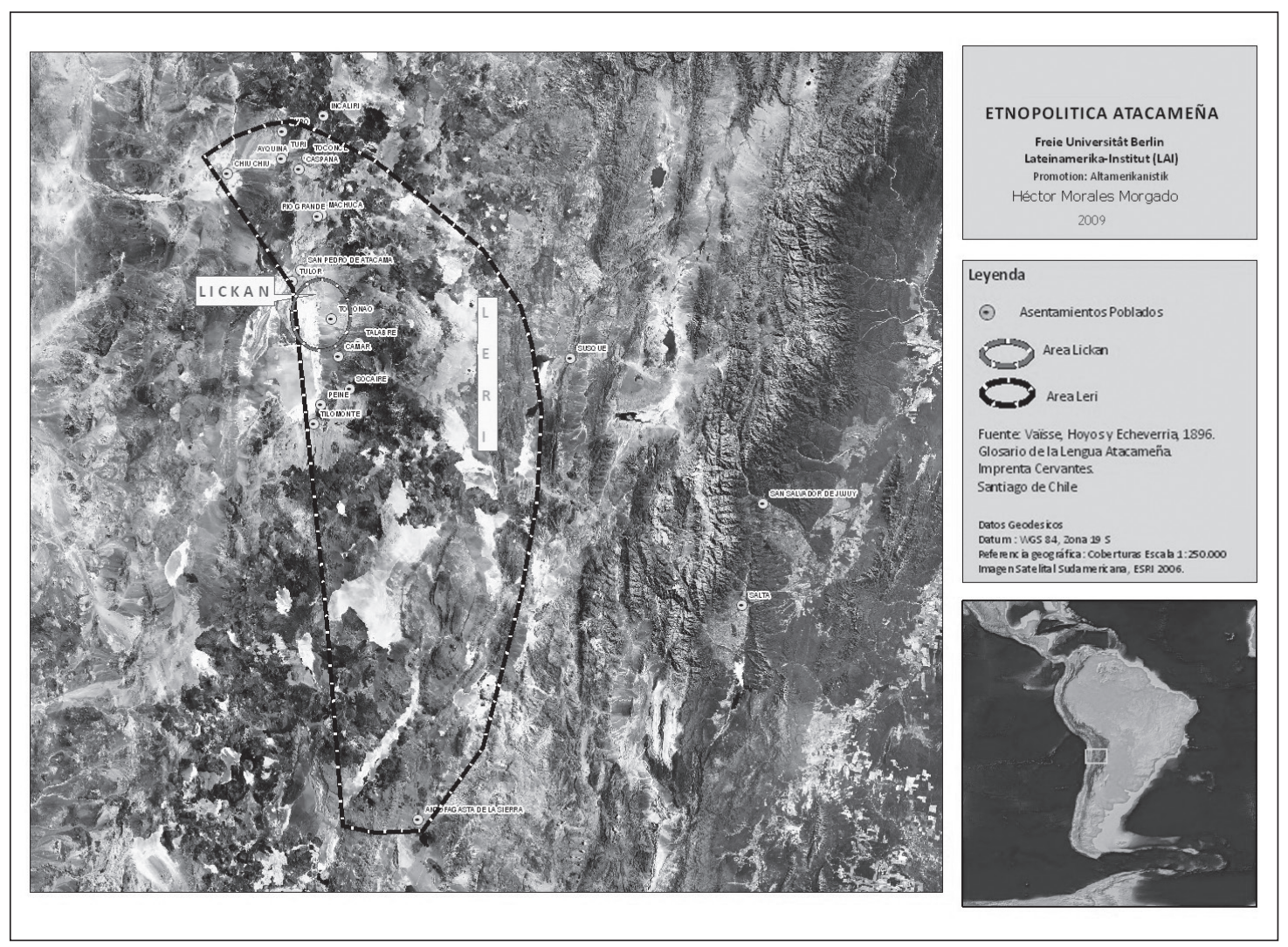

Figura 1. Nominaciones étnicas kunza (Morales 2010).

Según lo expuesto, no existe consenso respecto del origen y afiliación de la lengua de "los atacamas" o atacameños. No obstante, por un lado, las descripciones apuntan a dar coherencia a una unidad administrativa homogénea y diferenciada de sus vecinos (Philippi 1860; Moore 1877; San Román 1890), y por otro, a inscribir la tradición atacameña dentro de una unidad mayor con cabecera en la nación diaguita (Tschudi 1869; Vaïsse et al. 1896; Schuller 1908), abarcando gran parte de las unidades coloniales existentes, y que incluían a Chile, Argentina y parte de Bolivia. Estos naturalistas, misioneros y administradores estatales del s. XIX, son contratados por el Estado de Chile para delimitar una unidad administrativa funcional a los intereses estatales en esta zona. No es menor el hecho que Philippi recorra estos lugares cuando aún pertenecen a Bolivia, 25 años antes de la Guerra del Pacífico. Con posterioridad a la guerra, era clave otorgar unidad a esta región y las hipótesis de Tschudi (1869) y de Schuller (1908) no son fun- cionales a la integración de este territorio a Chile, pero sí lo será la hipótesis de San Román (1890) que asigna pertenencias de estas poblaciones y territorios al mundo andino septentrional.

El corregimiento de Atacama comprendía una zona allende los Andes, esta unidad territorial administrativa presentaba rasgos culturales comunes, todos hablaban la lengua kunza. Vaïsse (1894) asegura que así ocurre en pueblos como Susques, Catua, Antofagasta de la Sierra y otros más que él suele visitar pastoralmente desde el Curato de San Pedro. Esta franja, hoy parte de Argentina, pertenecía a Atacama, desde donde se ejercía control administrativo y religioso. Después del Tratado de 1899, pasó a engrosar la provincia de Jujuy y la de Salta, en Argentina. ${ }^{5}$

\footnotetext{
5 Vaisse y colaboradores (1896) mencionan la dependencia del idioma kunza con la nación calchaquí.
} 
Para reafirmar lo anterior, en investigaciones sociolingüísticas muy recientes se ha establecido que "La fitonimia en el área de San Pedro de Atacama proporciona evidencia de que, en el pasado, se hablaron tres lenguas aborígenes: quechua, aymara y kunza" (Sánchez 1998: 1), reafirmando la diversidad de grupos culturales en Atacama a través del tiempo, hecho que se expresa en las nominaciones sobre el entorno natural y social.

Otros relatos nos entregan arqueólogos en Atacama. Se inician con Uhle $(1912)^{6}$, quien fue uno de los primeros investigadores en otorgar un significado étnico y cultural a la palabra "atacameño" para referirse al registro arqueológico de un área y época prehispánica determinada. Años después, Oyarzún (1935) y Latcham (1938) retoman estas concepciones étnicas, refiriéndose a los materiales y sitios arqueológicos como partes de la cultura atacameña.

Los planteamientos de esos investigadores continuaron influenciando a otros estudiosos en una época en que el prisma que regía la antropología del norte de Chile rara vez dejaba ver otra cosa que no fuera "atacameños" (Castro 1998: 9). En este contexto Mostny (1954) publica su trabajo realizado en Peine, al sur del Salar de Atacama.

En 1954, el sacerdote jesuita belga Gustavo Le Paige llega a vivir a San Pedro de Atacama, iniciando así una larga trayectoria de investigaciones arqueológicas, bajo el enfoque de estudios de secuencias, plantea una continuidad cultural de larga data para los atacameños.

Durante el Primer Congreso de Arqueología Chilena realizado en San Pedro el año 1963, Le Paige defiende la tesis de continuidad cultural de los atacameños desde tiempos prehispánicos hasta la actualidad. Contrariamente a lo planteado por él, este congreso discute y acuerda abandonar las categorías étnicas en la designación de las culturas prehispánicas y sustituir la denominación "Cultura Atacameña" por la de "Complejo Cultural San Pedro" (Castro 1998: 10; Orellana 2006). Sin embargo algunos investigadores continuaron hablando de "atacameños" en su ter-

${ }^{6}$ Es quien inicia la etnificación de la data arqueológica con el etnónimo atacameño, contribuyendo a crear el imaginario sobre este pueblo originario y propio del norte de Chile, en oposición a lo aymara (Bolivia) y quechua (Perú). minología de sitio-tipo, como Núñez (1992). Entre otros, que dan adscripción étnica al registro arqueológico se mencionan a Mostny, Le Paige y Bittman (Ayala 2006).

En ese contexto se discutieron nuevas ideas, se evaluaron los antiguos problemas y métodos de investigación y se comenzó a cuestionar la unidad cultural atacameña con la influencia de los estudios regionales en arqueología. De este modo, se enfatizó en las particularidades locales, se definió una serie de periodificaciones y se identificaron complejos y fases culturales en vez de étnicas.

La discusión fue enriquecida sustancialmente con las investigaciones realizadas en el Loa Superior, las cuales, influenciadas por el planteamiento de Murra (1972) acerca de la verticalidad ecológica, postulan el arribo de una colonia altiplánica en Toconce, en períodos tardíos de ocupación (Aldunate et al. 1981; Berenguer et al. 1984). Esto conllevó a la identificación de grupos locales en Atacama y población foránea del altiplano, definiéndose las tradiciones del desierto y altiplánicas que se convirtieron en uno de los marcos referenciales más importantes de la arqueología nortina (Schiappacasse et al. 1989; Castro 1998; Uribe y Adán 2003).

Las nominaciones formalizadas a través de escritos e informes nos permiten fundamentar la adscripción étnica de los habitantes de Atacama. Así el concepto "atacameño" difundido ampliamente por los arqueólogos para la prehistoria, es adoptado por las organizaciones indígenas contemporáneas para dar nombre y profundidad cronológica a su cultura y patrimonio étnico.

\section{* Atacameños, collas y quechua}

Nos detendremos en la sociedad atacameña de fines del s. XIX, porque se encuentra un conjunto de documentos escritos y memorias de una época cruzada por tres acontecimientos (mercantilización a propósito del traslado de ganado de Argentina a Chile por esta zona, la Guerra del Pacífico y la chilenización ${ }^{7}$ de Atacama), que fundarán y

\footnotetext{
7 La chilenización de Tarapacá (1880-1922) (González 2002) y para San Pedro de Atacama (Mercado 2007) respectivamente, es la denominación utilizada para designar un proceso de aculturación de las zonas ocupadas o incorporadas por Chile, tras la Guerra del
} 
fundamentarán un proceso de formación de sujetos sociales y una etnogénesis ${ }^{8}$, a nuestro parecer, paradójica.

La sociedad atacameña de los oasis de San Pedro de Atacama, asumirá el control de una actividad económica altamente estratificada, asociada al traslado y alimentación de ganado, serán ellos quienes denominarán a sus vecinos según su conveniencia y funcionalidad. Encontraremos que a los habitantes de la Puna se les designó como "collas" y a las poblaciones de el Loa se les nombró como "quechua" o "bolivianos". En la actualidad, se mantienen estas adscripciones, ambos grupos nominados reconocen al kunza como lengua ancestral y al mismo tiempo, mencionan que la adscripción tanto de colla como de quechua o boliviano, apunta a degradar su condición.

El marcador cultural lingüístico, ha permitido, en Atacama, la diferenciación con otros grupos culturales, como vimos en relatos de naturalistas, misioneros, administradores y arqueólogos en Atacama, en distintas épocas. Por lo tanto, si hay algo que da unidad a las poblaciones de la Puna de Atacama, de San Pedro de Atacama y de la cuenca de el Loa es su memoria respecto del idioma nativo, el kunza. No debemos olvidar que estas poblaciones pertenecían al Corregimiento colonial de Atacama (Figura 2).

\section{La sociedad atacameña a fines del s. XIX}

Desde mediados de este siglo en adelante, existió en San Pedro de Atacama una estratificación socioeconómica que diferenciaba a los grandes propietarios y comerciantes de los indígenas. Estos últimos, sin embargo, presentaban importantes diferencias según su disponibilidad de medios productivos y condición de propietarios o trabajadores asalariados:

"La jente algo acomodada es casi toda comerciante o traficante en ganado que se importa de la República Arjentina. Los indios propietarios tienen la mayor parte de sus terrenos con alfalfa, otra con maíz i la menor con trigo o cebada; cosechan también la fruta del algarrobo [...] i la del chañar [...]. Los indios menos acauda-

Pacífico, con la finalidad de instalar tradiciones y valores culturales chilenos a las poblaciones locales de esa zona del país.

8 Será la emergencia de un sujeto social, también se entenderá como un proceso de transformaciones identitarias (Abercrombie 1991; Boccara 1999, 2002; Albó 2000). lados tienen su pequeña recua de burros i se ocupan en acarrear a Caracoles leña de pingo-pingo, de romerillo, etc. En fin, los que nada tienen se ocupan de segadores, jornaleros, etc." (Bertrand 1885: 272, en Sanhueza y Gundermann 2007).

Este tipo de diferenciación económica es perceptible también durante el período boliviano. La población indígena conformaba un estrato tributario con una bien diferenciada condición política, social y económica respecto del grupo dominante en la estructura social. No obstante, ello no impidió que por vía de su inserción en redes mercantiles, un sector indígena alcanzara un poder económico, incluso mayor que el que pudieron ostentar algunos ciudadanos bolivianos. Al describir la actividad productiva y comercial de los pobladores de San Pedro de Atacama, poco antes de la Guerra del Pacífico, Vidal Gormaz (1879, cit. en Sanhueza 2007), destacaba entre las principales fortunas del pueblo al menos dos casos correspondientes a indígenas que eran importantes propietarios de ganado, tierras y capital en dinero. Es muy probable que este tipo de movilidad económica haya permitido a algunos tributarios el acceso a la condición social de "vecinos", atendiendo a la común relación entre posesión de bienes y estatus social.

Posteriormente, como consecuencia de la Guerra del Pacífico (1879-1884) el Estado chileno anexó a su territorio una enorme extensión de tierras y recursos, actualmente correspondientes a las regiones del Norte Grande. Los principales intereses económicos que desataron el conflicto bélico se congregaban específicamente en los campos de salitre del desierto intermedio y en los puertos del Pacífico. Sin embargo, y aunque aparentemente no estuviera entre sus objetivos iniciales, el dominio chileno terminaría incorporando también los territorios interiores de las hasta entonces administraciones peruana y boliviana. En el caso de Bolivia, el Distrito Litoral o Lámar, cuya capital era el puerto de Cobija, incluía, en el desierto y tierras altas del interior, la subprefectura de Atacama. Su anexión conllevaría la incorporación definitiva de su población a la jurisdicción chilena.

La arriería constituyó, desde los inicios del período Republicano boliviano (1825-1884), uno de los principales rubros económicos desarrollados por los indígenas de Atacama. Esta actividad permitió acceder al circulante necesario para cubrir el pago anual de las tasas y la in- 


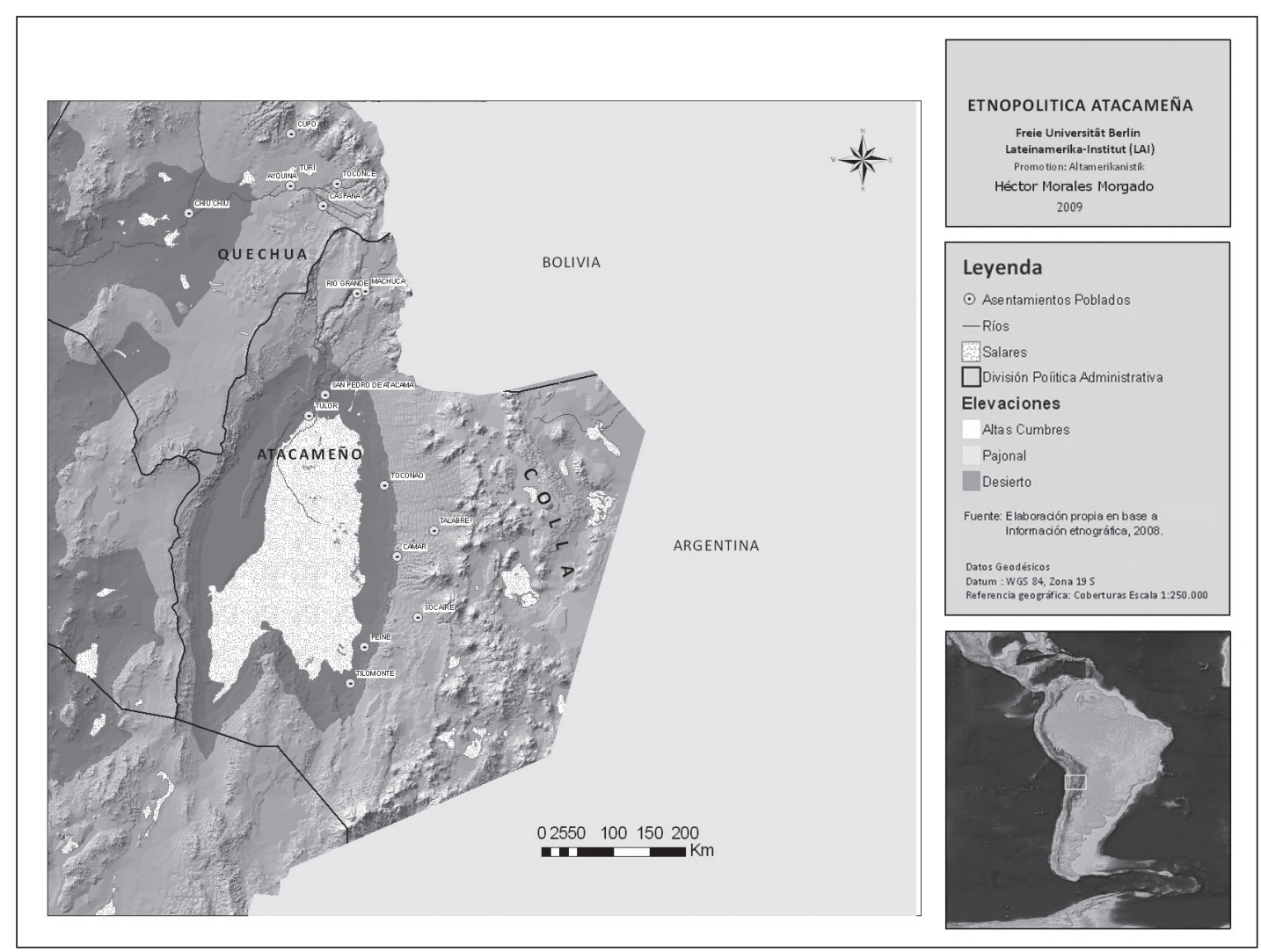

Figura 2. Nominaciones étnicas atacameñas (Morales 2010).

serción de al menos una parte de las economías comunitarias locales en el nuevo orden neocolonial. Articulando estrategias mercantiles con estrategias tradicionales de movilidad, la arriería permitía integrar la producción agrícola, ganadera y minera local, así como la intermitente actividad portuaria con los principales mercados altiplánicos. La población tributaria de Atacama era frecuentemente descrita como "arriera", especialmente los habitantes de la región del río Loa, ruta obligada entre el puerto de Cobija y el Alto Perú. Durante este período, el concepto de "arriero" se aplicaba al individuo que se dedicaba al flete o transporte de productos a lomo de mula, y que combinaba el comercio o intercambio de bienes propios o adquiridos por su cuenta, con el trabajo asalariado, trasladando mercancías pertenecientes a funcionarios o particulares españoles. Los arrieros de Atacama, a pesar del costo elevado que significaba su adquisición, con frecuencia fueron dueños de las mulas con las que trabajaban $y$, al menos en los viajes a larga distancia, este animal de carga logró desplazar a los camélidos (Sanhueza 1992; Siárez 1998).

Hacia mediados del s. XIX, Philippi (1860) calificaba a la arriería como la principal ocupación de los atacameños, describiendo un intenso movimiento de mercaderías desde Cobija a los valles tarijeños y a las provincias argentinas, introduciéndose también productos marinos adquiridos por intercambio con los indígenas de la costa. Los arrieros atacameños adquirían las mulas de los argentinos que introducían ganado por San Pedro de Atacama y posiblemente también las compraban directamente en los valles de Salta. Aunque su valor en el mercado era considerable, la demanda de fuerza de trabajo para los fletes y el comercio interregional de productos hacía rentable su adquisición.

Sin embargo, a fines del s. XIX, la habilitación del ferrocarril (1892) a través de la ruta de el Loa provocaría un 
duro golpe a esta actividad; pese a ello, la arriería local mantuvo como uno de sus destinos más importantes el campo minero de Caracoles ${ }^{9}$, que aún absorbía un importante tráfico indígena proveniente de los oasis de San Pedro de Atacama y de el Loa. Los arrieros puneños conducían allí sus pequeñas tropas y comercializaban alfalfa y leña, proveyéndose de otros artículos y víveres.

Con el desarrollo económico en la zona de el Loa los traslados comenzaron a volcarse hacia ese sector, principalmente a través del suministro de combustible. La yareta, (Azorella compacta) que se había vuelto indispensable para el funcionamiento de la industria minera, era recolectada y transportada a lomo de burro o de llama a los centros mineros e industriales. Sin embargo, crecientemente su puesta en el mercado se efectuaría a través de intermediarios que la comercializaban a bajo precio en las estaciones del ferrocarril. También el comercio de pieles de vicuña (Vicugna vicugna) y de chinchilla (Chinchilla lanigera), conformaron otro rubro intensamente explotado, en particular por las poblaciones de la cordillera. La piel de chinchilla era altamente cotizada como mercancía de exportación y, como en el caso de la yareta, se establecieron despachos especiales en algunas estaciones del ferrocarril para adquirirla o se contrataba agentes intermediarios para que la intercambiaran por hojas de coca u otros productos en los distritos puneños. Esta participación de intermediarios y casas comerciales para la puesta en el mercado de ciertos productos era frecuente y lucrativa. No obstante, la mercantilización de la producción indígena no solo estaba regulada o supeditada a la demanda de los mercados o agentes no indígenas. También una parte de sus productos, incluso aquellos de carácter "tradicional" y de consumo culturalmente restringido, participaba del sistema de circulación monetaria y mercantil (Vaïsse 1894).

Se presenta a una población con actividades insertas en los mercados regionales, con productos y producciones claves para el mantenimiento de las labores mineras, con toda seguridad, con una fuerte estratificación social y especialización derivada de la división social del trabajo en Atacama.

9 En 1870, el descubrimiento y explotación por capitales chilenos del mineral de Caracoles, situado en territorio boliviano, dio un último impulso a la minería de la plata.

\section{Atacameños, residentes de San Pedro de Atacama}

La sociedad atacameña de fines del s. XIX, está compuesta por familias propietarias españolas, cholas o criollas; argentinas, bolivianos o chilenos; los documentos de la época diferencian claramente diversos sujetos sociales, y los atacameños son diferentes de la población boliviana criolla y chola entre otras.

"Los documentos del Archivo Judicial de Antofagasta, del Archivo Nacionaly del Archivo Militar encaran diversos puntos ciegos de la memoriografía regional, hiatos historiográficos que son claves para comprender la transformación social e institucional del área al instaurarse la soberanía chilena. Chapetones y cholos, criollos y mestizos; españoles, argentinos, bolivianos o chilenos, los documentos diferencian claramente a los indios -también llamados naturales o indígenas. Hasta hoy, son precisamente estos cercos racializados los que dan cuerpo y color a las desigualdades en las relaciones económicas de la región entera [...]" (Barros 2008: 120).

El escenario social en Atacama a fines del s. XIX es complejo, estratificado y jerarquizado, con un grupo social de propietarios y comerciantes blancos, con medianos y pequeños propietarios indígenas que administran la producción de sus pequeñas pero fértiles tierras. Lo primero que hay que decir es que esta es una sociedad de agrupaciones ubicadas en lugares con fuertes límites dados por la capacidad de irrigación y las restricciones que impone el desierto.

“[...] cuando hablamos de 'atacameño' debemos remitirnos a una sociedad de campesinos asentados en torno a la tierra, que quedan definidos en su relación con la tierra por esas relaciones políticas, pero también por un marco local de vida y de relaciones sociales. Atacama es una región que tiene limitaciones ambientales importantes, sobre todo para la agricultura" (Gundermann 2002: 11).

Podríamos definir y enmarcar la condición socio-productiva del atacameño como un poblador rural campesino que trabaja la tierra, utiliza mano de obra familiar, la división del trabajo es por sexo y edad, es propietario de los instrumentos de producción y ocasionalmente contrata fuerza de trabajo externa.

Bertrand señala que San Pedro de Atacama estaba poblado por una mayoría casi exclusiva de "indios civilizados", 
dentro de los que se podían encontrar tanto "indios propietarios" como "indios menos acaudalados" (1885: 271272). Se destaca en estas afirmaciones el hecho de que un indio podía "refinarse", habitando un pueblo que contara con las comodidades básicas propias de la vida moderna. De esta manera, señala la factibilidad de "civilizar" a los indios atacameños. Lo que importa destacar por el momento, es que la diferenciación entre los pobladores de la Puna y de los poblados de tierras más bajas, encierra un evidente juicio de valor sobre las costumbres "bárbaras" en contraste con las "civilizadas", principalmente a partir de otra dicotomía: pastor vs. agricultor, o trashumante vs. sedentario. Sin duda, la distinción de "indio acaudalado" nos entrega información sobre divisiones sociales al interior de la sociedad atacameña.

Pese a los cambios en la actividad ganadera ya mencionados, a fines del s. XIX la internación de ganado por San Pedro de Atacama era considerada la fuente del bienestar de los atacameños, puesto que constituía el principal mercado para la producción agrícola forrajera local (Vaïsse 1894). Aunque los grandes comerciantes de las casas importadoras eran también importantes propietarios de una buena proporción de las tierras perteneciente a las familias indígenas de la localidad.

"Según el listado de contribuyentes efectuado por la Tesorería de Antofagasta en 1893 (AJA Leg. $847 n^{\circ} 13$ ), un total de 100 propietarios, incluyendo algunos de Toconao, debían pagar anualmente un $2 \%$ del avalúo de sus bienes muebles e inmuebles. Si consideramos pertenecientes a las familias bolivianas y argentinas de la región, a otros propietarios instalados con posterioridad a la guerra, y a una mayoría compuesta por antiguos tributarios o hijos de tributarios indígenas... Aunque no entrega especificaciones respecto a los bienes avaluados, el documento permite una aproximación a las proporciones existentes en la distribución de la propiedad. Si establecemos categorías según los montos que debían cancelarse y la procedencia social de los contribuyentes, se puede señalar que los más altos correspondían a dos miembros de las tradicionales familias de origen boliviano (que pagaban 52 y 46 pesos, respectivamente). ${ }^{10}$ El rango que la población de

\footnotetext{
${ }^{10}$ Según Sanhueza y Gundermann (2007), no es posible determinar en todos los casos el origen sociocultural o nacional de los contribuyentes registrados. Sin embargo, el análisis comparativo de las diferentes fuentes consultadas para este período y para el boliviano (particularmente de los padrones de revisitas) permiten establecer una identificación razonablemente segura de las familias de origen
}

esta capital se calculaba en aproximadamente 1720 habitantes (Vaïse 1894), suponemos que un número importante no pagaba contribuciones. No obstante, el registro de contribuyentes corresponde a vecinos siguiente, mucho más bajo y bastante amplio, incluía vecinos pertenecientes a esas y a otras familias bolivianas $y$ argentinas, junto con contribuyentes de origen indigena tributario. Ellos cancelaban, indistintamente, montos que abarcaban entre los $\$ 26 y \$ 7$. A partir de alli distinguimos un tercer rango que incluía desde los $\$ 6$ en escala descendente y se componía de población casi exclusivamente indígena en una magnitud cercana al 60\% del total de contribuyentes" (Sanhueza y Gundermann 2007: 22).

Aunque los indígenas, por lo general tenían propiedades de menor tamaño y muchos no pagaban, estos datos permiten señalar que, al menos en lo que se refiere al rango de los medianos propietarios, mantenían una participación significativa. Esta condición de "contribuyente", junto con representar una carga impositiva, constituía una forma de reconocimiento social, especialmente en aquellas localidades de mayor densidad y heterogeneidad poblacional. El hecho de pagar impuestos legitimaba una relación con el aparato fiscal chileno y supone la afirmación de derechos de propiedad. Por ello es que estos primeros roles de avalúos pudieron tener una buena recepción entre los propietarios, en ausencia de una titulación de la tierra actualizada. Pero, al mismo tiempo, estos procedimientos administrativos inauguraban una forma distinta de relación entre los indígenas y el Estado chileno, ya que en este contexto los ex tributarios del sistema estamental boliviano se situaban -aunque no fuera sino desde el punto de vista de las cargas impositivas - en una posición de igualdad respecto al resto de los contribuyentes. Desde esa perspectiva, se establecía no solo una nueva relación económica con el Estado, sino también se sentaban las bases para una nueva relación política. Una más próxima a la condición de ciudadanos, aunque ésta fuera en muchos sentidos meramente nominal (Gundermann 1998).

Esta situación de propietario y productor agrícola consolidará una posición social de superioridad y hegemonía sobre sus vecinos pastores de la Puna y los inmigrantes

\footnotetext{
boliviano, argentino e indígena tributario. En el caso de estas dos principales fortunas mencionadas, se trataba de ciudadanos bolivianos pertenecientes a las familias Ríos y Hoyos, señaladas entre las más poderosas de la localidad antes de la guerra.
} 
bolivianos; ambos grupos serán catalogados como "atrasados" y "pobres", por esta élite mestiza, los atacameños, que se ubica en la cúspide de una jerarquía clasista y racista.

Respecto de los procesos identitarios experimentados a fines del s. XIX e inicios del XX en esta área de estudio, se plantea que la transformación de una identidad indígena hacia una ciudadana chilena, implicó un complejo proceso de redefinición de fronteras étnicas, en el que un sector de la población dejó de considerarse a sí mismo como indígena (Morales 2010).

En este escenario surge una identidad social territorial "atacameña", con una fisonomía de ciudadano alfabetizado, con un comportamiento moralmente adecuado y su condición de propietario. Quién cumpla con estos requisitos obtendrá progresivamente su condición de chileno ciudadano.

Desde una perspectiva etnográfica, Sanpedrino Poncho Colorado. A los pobladores de San Pedro de Atacama, se les decía a modo de burla "Poncho Colorado" debido a que sus vestimentas y particularmente sus ponchos se teñían con el color de la greda de las murallas de sus casas. El poncho sin duda es un símbolo del campesino chileno, que marcará la diferencia respecto de la vestimenta con sus vecinos. ${ }^{11}$

Los relatos a continuación nos muestran las diferencias culturales comprometidas en las nominaciones, tienen un fin académico y nos permiten dar cuenta de fricciones

\footnotetext{
${ }^{11}$ Asimismo, dentro de la población de San Pedro existen distintas nominaciones para designarse entre ellos; son muy antiguas y nos muestran una particular forma de nominar a las poblaciones vecinas a San Pedro de Atacama. Por ejemplo: "Toconao", "toconares", "bolsa sucia", hacen referencia a la antigua actividad de recolección de "breas" [brevas], fruta silvestre comercializada en los mercados locales que teñía su vestimenta de color oscuro (Margarita Chocobar, concejal municipal, com. pers. 2009). "Solor", "soleño", "lomo negro", hacen referencia a dos situaciones: la utilización de la espalda como medio de transporte y el color de la piel oscura. "Sequitor", "sequiteño", "panza áspera", hacen referencia a la exposición del estómago a la tierra y el sol. "Catarpe", "catarpeño", "cola pelá”, este último se refiere a los roedores sin pelos en la cola, que circulan por las siembras, destruyendo y robando comida (Rubén Reyes, consejero nacional atacameño, com. pers. 2009).
}

y fisuras ${ }^{12}$ sociales e históricas entre los diversos grupos que conviven en la zona de Atacama.

Esta fuente se identificará de manera discreta, pues sus relatos nos grafican las cargas raciales de prejuicios existentes en la actualidad, que responden más a una estructura social de la diferencia en una zona de fronteras culturales, que a opiniones individuales;

"[...] los de San Pedro de Atacama somos diferentes a los pueblos de interior, ellos son flojos y borrachos, además los niños de arriba son más lentos, yo le he hecho clases, le he enseñado a padres e hijos, en cambio los niños de San Pedro y sus ayllus son más rápidos" (Profesora atacameña 2008).

Este relato podría ser parte de un sinnúmero de narraciones posteriores a la Guerra del Pacífico a fines del s. XIX, cargado de juicios de valor respecto de los pobladores del interior de San Pedro de Atacama. Pero no es así. Es un relato recopilado el año 2008; es más, pertenece a una profesora que educa tanto a los niños de San Pedro de Atacama como a los niños del interior que llegan a su escuela. Sus expresiones solo reafirman la convicción férrea de una imagen de modernidad y desarrollo, de la bondad del trabajo, la rapidez de estos tiempos de internet y globalización.

El verdadero enfrentamiento cultural es evidente cuando se menciona que los profesores de la escuela deben enseñar a los niños del interior:

"[...] lo que es un dormitorio, una cama, un velador, ellos no usan esas cosas, duermen todos juntos en una pieza; la verdad es que cuesta mucho enseñarles los valores, generación tras generación se comportan de la misma manera" (Profesora atacameña 2008).

\footnotetext{
12 Recogemos la definición de Cardoso (1964, 1992) y Barth (1976 [1970]), donde se presenta la fricción interétnica como una forma de describir la situación de contacto, entre grupos étnicos irreversiblemente vinculados unos a otros, a través de los conflictos (manifiestos) o las tensiones (latentes) existentes entre ellos. Por otro lado, la idea de "fisuras generativas" de Valenzuela (1999) diferencia las rupturas sociales e históricas perdurables por largo tiempo que tienen un papel importante en la estructuración de espacios sociales locales y que la tienen, en la medida que dan origen a agentes sociales y a una acción social concomitante con ellas. Lo interesante de las fisuras es que producen alineamientos de sujetos, definiciones de propósitos, especificaciones de identidad e identificación.
} 
Lo señalado no hace más que reafirmar las diferencias sociales e incluso culturales que se mantienen pese al desarrollo socioeconómico que ha experimentado la zona.

La misma informante nos señala:

"Las diferencias son sustanciales entre collas y atacameños, nosotros debiamos tener pocos hijos y casarnos, hay diferencias culturales muy fuertes. Las mujeres collas tienen muchos hijos con distintos padres, pero no les importa. Si yo hubiese tenido un hijo soltera me echan de la casa, son pobres y a ellos les da lo mismo. Ellos tienen otros valores, las jóvenes no usan anticonceptivos, se les enseña, pero su cultura es más fuerte, se casan entre ellos, nunca se casan con gente de afuera de sus pueblos, incluso se ha conocido de nacimiento de bebés producto de la relación de abuelo con nieta" (Profesora atacameña 2008). ${ }^{13}$

Todas estas diferencias necesariamente aglutinarán juicios cruzados respecto de comportamientos adecuados y las verdaderas amenazas para la convivencia entre los grupos de Atacama.

Por su parte, la escritora atacameña Eva Siárez, nos da la profundidad histórica para el examen cuidadoso del siglo pasado. Nos menciona que, a partir de sus recopilaciones, se aprecian fuertes diferencias sociales y económicas entre los pobladores de Atacama:

“[...] acá en San Pedro somos propietarios y agricultores desde hace mucho tiempo, desde cuando traían animales desde Argentina, a mediados del s. XIX, los productores agrícolas de San Pedro de Atacama producían básicamente alfalfa y maíz".

Siárez nos remonta al s. XIX, y agrega en la entrevista de 2009:

"Las remesas de ganado la coordinaba la familia Abaroa, de origen español, que llegó a la zona a principios del s. XIX; él le compraba a todos el pasto, imagínese, 90 vacunos machos alimentándose por dos o tres días. Finalmente Abaroa, hijo, muere defendiendo su terreno en manos de las milicias chilenas en la

${ }^{13}$ Este es un juicio temerario respecto de un "otro" cultural; ello evidencia diferencias culturales y no solo sociales o de clase. Cabe mencionar que se inscribe en una estructura social que hace plausible apreciaciones y juicios colectivos dentro de situaciones de fronteras culturales.
Guerra del Pacífico, pero él no se consideraba ni boliviano ni chileno, pero sí se decía atacameño".

El relato reafirma datos de fuentes históricas de fines del s. XIX. ${ }^{14}$ Los propietarios atacameños de San Pedro de Atacama, con toda probabilidad desde la llegada de Juan Abaroa en 1809 en adelante, van a consolidar un sistema de producción forrajera destinada a la alimentación de los animales trasladados desde Argentina a las costas del Pacífico. Al mismo tiempo, el encadenamiento productivo va a generar una fuerte división social del trabajo, que se materializó en segmentos sociales que en algún momento adquieren connotaciones de verdaderas clases sociales al interior de la sociedad atacameña.

Siárez, nos menciona ciertas características del arrierismo:

"Los arrieros eran gauchos argentinos, blancos con bigote, machos, conocedores del clima y de buena salud y fuertes. Ellos llegaban hasta San Pedro con los animales, luego contrataban a los collas de la cordillera, para que los llevaran hacia Calama, ellos conocían el camino, el clima y estaban acostumbrados a esas caminatas. Cosa que jamás hubiese hecho un atacameño, estos eran agricultores y gente de campo, de caballo" (Eva Siárez, com. pers. 2009).

Las poblaciones de la Puna participan del arrierismo como conocedores de rutas y adiestrados para los largos recorridos por el desierto. Aquí queda en claro las cualidades de los pobladores cordilleranos en las faenas de traslados de animales y la necesidad de contratarlos para algunas faenas.

"Los atacameños con el dinero que recibian de la producción agrícola, compraban ropa, caballos, alimentos y carretas. Encargaban a Cobija muebles, instrumentos musicales (piano y violín), veladores, mesas y peinadores de mármol, todos traídos de Europa; unas inmensas carretas con grandes ruedas. Incluso yo aún conservo tazas de té de loza inglesa de fines del s. XIX. Es posible que en las oficinas salitreras llegaran estas cosas y por eso aquílas compraban" (Eva Siárez, com. pers. 2009).

Las utilidades y ganancias de la producción agrícola se expresa no solo en mobiliario doméstico, sino también

${ }^{14}$ Intencionalmente no haremos la distinción entre Atacama boliviano o chileno por ser irrelevante, los acontecimientos ocurren en una zona prácticamente olvidada por el Estado, sea uno u otro. 
en la compra de propiedades en la ciudad de Calama, según nos dice Siárez; hasta hoy la familia Hoyos y otras continúan siendo dueños de las propiedades más importantes de Calama.

Por las descripciones entregadas hasta aquí, los atacameños de San Pedro de Atacama son un tipo de campesino propietario con capacidad de acumulación de riqueza. Ello se materializará en la adopción de patrones de comportamiento y adquisición de mobiliario europeo.

"Los atacameños de principio de s. $X X$, son mestizos y españoles con comportamientos criollos, dueños de tierras, en sus casas se toca el piano y el violín y las señoras andan de polleras largas, españoladas" (Eva Siárez, com. pers. 2009).

La caída de este estilo de vida se debió básicamente a la instalación del ferrocarril (1899), que restringió los viajes por el desierto, y al cierre de las oficinas salitreras (1930). Después de eso:

"[...] desde 1930 en adelante, los pastores cordilleranos prácticamente no venían a San Pedro y cuando lo hacían traían tejido, carne de llamo, lazos; solo existía trueque económico, no hay intercambio social. Todo esto ocurre hasta la década del 60 y 70 , cuando el cura Gustavo Le Paige los trae, argumentando que estaban solos y había que educarlos" (Eva Siárez com. pers. 2009).

Los propietarios atacameños de San Pedro, poco a poco ven una amenaza en la llegada de las poblaciones del interior. A su modo de ver, éstos invaden los alrededores del casco antiguo y colonial de San Pedro, sus calles y mercados.

Haciendo referencia a Machuca, un poblado de la Puna cercana a San Pedro de Atacama, se dice:

"Los machuqueños se tomaban los terrenos en San Pedro y eso era un problema, por eso a la gente no le gustaba ver por acá, les llamaban collas, en esos tiempos [década del 50 y 60 ] los maltrataban, los trataban muy mal. Ellos siempre pobres, poco limpios, niños sucios, sin peinarse ni lavarse. Mi tío Francisco Mostajo, me decía 'la gente de pueblo odia a la gente de arriba' para qué educan a los collas si ellos no entienden" (Eva Siárez, com. pers. 2009).

Agrega que la sociedad atacameña era muy estricta:

"Mi papá jamás hubiese aceptado que me hubiese casado con un Colque o un Lique, decía: 'hay que mejorar en vez de empeorar, no más bajo, no más vago'. La gente de antes, atacameños, era racista y descalificaba a las poblaciones del interior" (Eva Siárez, com. pers. 2009).

Los relatos etnográficos aquí expuestos nos permiten deducir que la sociedad atacameña es heterogénea, con diversos grupos sociales en su interior. Los nuevos escenarios multiculturalistas buscarán homogeneizar y estandarizar un conjunto de fenómenos organizacionales de grupos históricamente denominados como indios o indígenas.

La paradoja se constituye en que pese a los esfuerzos de integración de esta población, será rotulada por poblaciones chilenas externas a Atacama, como indios. La campaña de chilenización de la zona será muy agresiva, todas las conductas que disten del canon de integración serán catalogadas como extranjeras. Por esta razón, los atacameños deberán alejarse de los estereotipos indios de las poblaciones avecindadas en la Puna atacameña (vestimenta, alimentación, rituales y lengua entre otros), situación que hoy sigue latente.

\section{Colla, pastores de la Puna atacameña}

El párroco de Atacama, Vaïsse (1894), establecía una clara distinción entre la población de la región del Salar, y aquella que habitaba la Puna, diferencia que fundamentaba en sus respectivos patrones de comportamiento. Es evidente el contraste de los agricultores atacameños con la población los pastores de la Puna, descrita como aislada de todo contacto externo, al margen de la "civilización y el progreso" por sacerdotes y funcionarios chilenos pos Guerra del Pacífico.

"[...] mientras los indios del lado occidental viven reunidos en poblaciones, los del lado oriental viven apartados unos de otros [...] De allí proviene el relativo adelanto de los que llamaré 'occidentales', mientras que los orientales están aún casi en las tinieblas" (Vaïsse 1894).

Esta elocuente oposición nos remite una vez más a la concepción aldeana como única forma de poblar un territorio, de acuerdo con el discurso reduccional colonial. Por su parte, funcionarios públicos como Bertrand y San

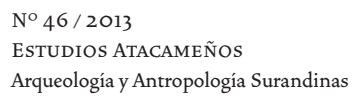


Román, que recorrieron la región en misiones oficiales, diferenciaban también a los indios "civilizados" de San Pedro de Atacama, de aquellos de "raza pura" de la Puna. Estos últimos fueron definidos en sus relatos como individuos de aspecto repugnante y en estado semi salvaje, o incluso en una posición límite entre la humanidad y la animalidad (Bertrand 1885; San Román 1896). Esta condición de marginalidad podía incluso adquirir valoraciones opuestas, como lo expresaba San Román en diferentes contextos en su obra respecto de la Puna:

\section{"[... caceríos dispersos de pobladores indíjenas en su más puro tipo de raza, con su idioma, trajes i costumbres conservados por directa sucesión, sin mezcla ni contacto estraño a su sangre i tra- diciones" (1896: 253).}

Serán los funcionarios públicos, verdaderos intelectuales que modelarán el imaginario de alteridad entre las poblaciones agricultoras y los pastores de Puna. Distinción que se fundará en diferencias culturales en una época de eurocentrismo y bajo la creencia evolucionista del desarrollo, es decir, la humanidad avanzaba de menos a más, siendo la sociedad chilena, el modelo civilizatorio.

“[... en plena Puna de Atacama, en medio de aquella raza indijena dejenerada, uraña a todo contacto con el hombre social; envilecida por la humillación; embrutecida por una ignorancia que escluye toda noción de cultura i lleva cada día más $i$ más a esas pobres jentes al divorcio con toda idea de civilización" (San Román 1896: 243).

Los pobladores rurales de la Puna son trashumantes, pastores de camélidos, que usan un conjunto de estancias o estructuras habitacionales temporales dentro de los circuitos de alimentación y traslado de animales. Esto condicionará su estilo de vida de pocos utensilios, habitaciones sin muebles, sin nociones de propiedad y sin motivación por la producción agrícola, características que aún se observan en los poblados de la Puna (Morales 1997; Castro 1997, 2000; 2001; Göbel 2002; Contreras 2005; Molina 2007a).

Aunque ubicada dentro del territorio nacional según las autoridades chilenas de fines del s. XIX, la población de la Puna atacameña nunca fue considerada como tal o como potencialmente "chilenizable". Esta negación involucraba también, al menos en este período, a la po- blación de las tierras bajas de la subdelegación. Según el intendente de Antofagasta, la única dificultad que presentaba la administración de San Pedro de Atacama era "la falta de chilenos, pues sus habitantes son en casi su totalidad indios". Los asentamientos de la Puna, a su vez, eran definidos como "[...] pequeños caseríos que no cuentan sino con uno que otro habitante chileno". Siendo en su mayoría 'indios semi-civilizados'" (Memoria del Ministerio del Interior 1894: 99, Sanhueza y Gundermann 2007: 122).

Es interesante constatar que, desde la perspectiva chilena, el concepto o categoría de "indio" solía estar exento de cualquier tipo de pertenencia nacional. Además, para el Estado chileno, a diferencia del boliviano, no existía el "indio tributario", ni por consiguiente la necesidad de un reconocimiento jurídico respecto a quienes integraban esta categoría fiscal. Por ello la presencia del "indio" se diluye o desaparece de la cartografía política y social, sin manifestarse interés alguno por promover su incorporación al territorio nacional. El proyecto modernizador soslaya sistemáticamente la integración diferencial, serán todos ciudadanos chilenos, siempre y cuando no se escapen de los moldes de comportamiento social y moral aceptable por el statu quo reinante.

La pertenencia nacional no solo será vista como un fenómeno unilateral, se atribuía también a la población indígena una actitud completamente pasiva e indiferente respecto a los procesos políticos y nacionales que se generaban en su entorno. Siendo "los infelices indios" meras víctimas de las guerras de independencia, las revoluciones y los conflictos internacionales, respecto de los cuales no tenían clara conciencia (Bertrand 1885: 271).

San Román, por su parte, establecía implícitamente un contraste o una "frontera" entre el espacio cultural puneño y la "civilización". Diferencia que radicaba fundamentalmente en la ausencia de toda idea de nación o nacionalidad en aquellos territorios "donde jamás había flotado emblema alguno de idea patriótica, profana o sagrada" (San Román 1896: 254). Evidentemente San Román confunde Estado con nación, pero no por ignorancia sino por su interés de instalar Estado en los confines del país, en una condición de multiculturalidad problemática para la integración social de las poblaciones indígenas. 
Estos juicios sobre civilización y raza, son la expresión de una época marcada por las concepciones evolucionistas y eurocéntricas, las que asociadas a otros calificativos van configurando una visión del indio, su integración y las posibles acciones del Estado sobre estos territorios anexados.

A modo de referencia, la bibliografía arqueológica, histórica, etnohistórica y etnográfica referente a la Puna de Atacama ha asumido una especial prudencia al referirse a las adscripciones étnicas de las comunidades pastoras del área (Martínez 1985; Castro y Martínez 1996; Castro 1997; Morales 1997, 2010; Sanhueza 1992; Göbel 2002; Contreras 2005; Molina 2007b).

Cabe mencionar que la Puna en Atacama opera como un ecosistema de montaña con sus oportunidades y debilidades expresadas en la utilización humana de cadenas tróficas y en la apropiación del espacio de altura.

"El movimiento de pastores y animales, fluctúa en directa relación al aumento o disminución de la vegetación forrajera, lo que determina las actividades pastoriles y el conjunto de movimientos trashumante" (Morales 1997: 63).

Muchas investigaciones señalan que los pobladores del borde occidental de la Puna de Atacama serían migrantes colla del noreste de Argentina. Se establece que en San Pedro de Atacama se hace una distinción entre los más indios, los llamados despectivamente collas por los habitantes de San Pedro de Atacama, y que alude a aquellos sujetos sociales que viven en los pisos altos, habitada por pastores que aún practican la trashumancia, y que serían más "indios" y más "morenos" que los habitantes de los oasis pie puneños (Rivera 1994; Garrido 2001; Morales 2010).

Desde una perspectiva etnográfica. Un dirigente de la Puna atacameña, poblador rural y alejado de los centros poblados y administrativos de San Pedro de Atacama, nos dice:

"Cuando se formó la comunidad indígena todo cambió, llegó ayuda al pueblo a través de proyectos. También existió más respeto de parte de la gente de Toconao y San Pedro. Antes habia mucha discriminación por ser gente de campo, nos llamaban despectivamente 'collas'. Nosotros por mucho tiempo fuimos a San Pedro y Toconao a cambiar lazos de lana de llamo, por trigo, azúcar, arroz, en ese tiempo no había dinero. Cuando llegábamos a los pueblos nos miraban mal y nuestra gente no podía ni siquiera levantar la cabeza ante los sanpedrinos. Con el Derecho indígena eso cambió, ahora uno puede hasta aforrarle [golpear] a alguien que te diga 'indio' o 'colla"' (Dirigente comunitario de la Puna 2009).

El dirigente nos menciona las diferencias sociales y la descalificación existente hasta antes de la Ley Indígena. ${ }^{15}$ Menciona que algo cambió, clarificando que:

“[... los pueblos o localidades de la Puna son Talabre, Peine, Socaire, Camar, Machuca y Río Grande, en cambio en San Pedro de Atacama hay ayllu Solor, Sequitor [...] y muchos más, Toconao también está en el Salar de Atacama y son agricultores igual que en San Pedro, muy distintos a Talabre" (Dirigente comunitario de la Puna 2009).

La distinción entre pueblo y ayllu es clave. Los pueblos pertenecen a la Puna cordillerana. Son poblados alejados del centro administrativo, con una fuerte actividad ganadera y una inserción laboral de los jóvenes en los grandes centros industriales mineros (Núñez 2002). En cambio los ayllu son las localidades pertenecientes al centro político administrativo, que es San Pedro de Atacama, fundamentalmente agrícolas y en los últimos 20 años empleados en la industria turística.

"Los atacameños siempre fueron los de San Pedro, después con la Ley Indígena se nos dijo que todos éramos atacameños, por eso hemos recibido más beneficios, se ha invertido en agua, luzy alcantarillado y en mejorar las semillas para las siembras y mejorar la crianza de los animales" (Comunera y artesana de la Puna 2009).

La Ley Indígena es un intento por homogeneizar la población en Atacama, la que -como hemos visto-

\footnotetext{
${ }^{15}$ La primera información que recibieron los pobladores de Atacama respecto de la Ley Indígena 19.253, aprobada en septiembre de 1993, se refiere a iniciar un proceso de inscripción de los, hasta ese momento, "poblado" o "localidades" en "Comunidades Indígenas Atacameñas”. Artículo $9^{\circ}$. Para los efectos de esta ley se entenderá por Comunidad Indígena, toda agrupación de personas pertenecientes a una misma etnia indígena y que se encuentren en una o más de las siguientes situaciones: a) Provengan de un mismo tronco familiar; b) Reconozcan una jefatura tradicional; c) Posean o hayan poseído tierras indígenas en común; y d) Provengan de un mismo poblado antiguo.
} 
presenta claras diferencias entre sus poblaciones. Las reformas legales de los gobiernos democráticos han apuntado a una integración homogénea de las poblaciones rurales indígenas. Estas políticas estabilizan y fijan identidades étnicas para su reconocimiento, y además, es una gran oportunidad para captar recursos económicos por parte de los grupos étnicos:

"La Ley Indígena ha ayudado mucho, hay más respeto y preocupación. Aunque es insuficiente. Antes nos decían a los talabreños 'indio' los de Calama, incluso los de San Pedro de Atacama también. Y la gente de acá, ni siquiera levantaba la cabeza cuando los ofendían, ahora es muy distinto" (Comunera y artesana de Talabre 2008).

Pese a los esfuerzos de la Ley Indígena de homogeneizar a la población, se evidencia aún discriminación entre los distintos grupos por sus diferencias.

"Ahora, según la Ley Indígena, los collas están en Copiapó y nuestros bailes de carnaval son iguales a los de ellos y son distintos a los pueblos del Salar. Nosotros usamos flauta y tambor, en cambio ellos usan acordeón "iquizás somos collas? a toda honra" (Dirigente comunitario de la Puna 2009).

En la actualidad, los sectores juveniles de la población de Atacama están utilizando el apelativo "runaco". ${ }^{16}$ Este es un descalificativo para referirse a cualquier conducta negativa que según ellos es propia de los indios: beber en exceso, falta de limpieza personal, hablar en forma poco entendible, entre otras cosas. Este es un alter aumentado en sus cualidades, por ello, se puede graduar la alteridad y extranjería de más a menos; colla, quechua, boliviano y finalmente la calificación de degradación máxima, "runaco".

"El pueblo Licanantay es muy diverso, la gente que vive en la cordillera [Puna] está muy emparentada con familias argentinas, por otro lado, los toconares siempre han mantenido férreas diferencias con la población de San Pedro de Atacama, antes, cuando yo era niña, poblaciones como Machuca o Talabre eran estancias

\footnotetext{
${ }^{16}$ Vocablo quechua que significa hombre (Schuller 1908). Runa, -co adj.s. m. y f. vocablo quechua derivado de runa, equivale a ser humano, gente. Castellanizado como adjetivo "runaco", se aplica para aumentar sus cualidades negativas. Un dicho popular jujeño clarificador "no soy ningún runaco de mal agüero" (Dirigente Indígena de Comunidad Aborigen de Catua, Jujuy, 2010).
}

dispersas y la gente raramente venía a San Pedro" (Dirigente de San Pedro de Atacama 2009).

Vemos así como la población rural de Atacama está marcada por antiguas divisiones sociales consecuencia de estilos de vida distintos, y pese a los cambios productivos que se han experimentado en los últimos años, las discriminaciones persisten y con ello la subordinación de los grupos de la Puna al centro administrativo de San Pedro de Atacama.

Una dirigente de la Puna de Atacama dice:

"Somos atacameños pero no somos hermanos, hay mucha envidia entre las comunidades, -lo atacameño-, es por conveniencia, porque las comunidades si pueden obtener beneficios solas, no les interesa el resto. Lo de Licanantay es una cosa de ahora, nunca se ha hablado de Licanantay, solo de atacameños, incluso los atacameños son los de San Pedro y sus ayllu y nadie más, ellos discriminaban mucho a la gente de la cordillera. Siempre nos discriminaron mucho, nosotros les matábamos el hambre cuando bajábamos con carne, siempre se juntaba mucha gente a comprar $y$ ahora es igual. Antes abusaban de nosotros por ser del campo, nos decían 'collas', 'collitas' y nunca nos dejaron establecernos en San Pedro de Atacama ni en Toconao, ahora sí. Cuando, yo era niña, bajábamos, llevábamos lazos y tejidos y los cambiábamos por semillas, azúcar, arroz, harina o simplemente pan duro" (Comunera y artesana de Talabre 2008).

Estos fragmentos nos muestran la persistencia de divisiones sociales de estas poblaciones:

"[...] los toconares siempre nos han tratado muy mal, se creen dueños de la tierra de Talabre, ellos nunca han pastoreado, sí nos traían sus animales y nosotros se los cuidábamos, como mediería, por eso ellos no pueden inscribir legalmente las vegas nuestras. Nosotros siempre intercambiábamos con ellos leña y carne por frutas y otras verduras" (Comunera y artesana de Talabre 2008).

Estas fricciones y rivalidades históricas se enfrentarán dentro de un marco regulatorio denominado Ley Indígena. El nombramiento de "atacameño", por parte de la Ley Indígena de todas las poblaciones de Atacama (collas y quechua), si bien atomiza a los grupos, es también la posibilidad de disminuir la doble discriminación que han sufrido, por décadas, las poblaciones de la Puna, 
accediendo a una categoría social con ciertos privilegios, no solo económicos sino también de estatus social.

Poco a poco se consolida la idea de un alter-colla, cargado con características negativas; borracho, sucio, lengua extraña, criador de llamo, finalmente el indio, por otro lado, un ego-atacameño campesino mestizo con hábitos criollos, su referencia cultural será la sociedad chilena de principios del s. XIX y con cualidades opuestas al colla; limpio, responsable, castellanizado y de hábitos modernos. La construcción de estereotipos sociales y la creación de oposiciones a partir de los estilos de vida diferentes, terminará irremediablemente con los clasificadores en la cúspide del desarrollo, los atacameños de San Pedro de Atacama.

\section{Quechua, residentes en la cuenca de el Loa y sus alrededores}

A pesar de las huellas coloniales y republicanas que han afectado a las poblaciones locales, es posible percibir elementos propios de tradiciones andinas diversas. En efecto, entre los rasgos culturales que caracterizan a las comunidades andinas de esta región se encuentran elementos que se han denominado "Tradición Altiplánica", con elementos de influjo quechua parlantes y de otros grupos que pueblan el altiplano. Por otra parte, están presentes elementos de otra tradición que, sobre la base de evidencias arqueológicas, ha sido denominada "Tradición del Desierto" representadas por las poblaciones del Salar de Atacama (Aldunate et al. 1981; Schiapacasse et al. 1989).

Cabe mencionar que la movilidad característica del área Centro-Sur Andina, generó una variada interdigitación de grupos étnicos que tendieron a cristalizar un patrón de complementariedad económica, social y política durante el período Colonial español. En este marco los nexos entre las poblaciones indígenas de la Tradición del Desierto (Salar de Atacama), Noroeste Argentino y Altiplano Meridional boliviano fueron evidentes (Martínez 1990, 1994).

Según Castro (1997), para el período prehispánico y Colonial, el enfoque sobre la etnicidad en la subárea Circumpuneña, se enfrenta a que:

[...] en tiempos prehispánicos, las poblaciones indígenas de la provincia de El Loa han mostrado una dinámica de relaciones que comprende un espacio macrorregional -las subáreas Circumpuneña y Altiplano Meridional- que incluye territorios de los actuales países de Argentina y Bolivia. No es posible entonces percibir a los atacameños, sin por lo menos esbozar otras probables identidades que están en juego. Estamos hablando de una zona de gran permeabilidad del tramado étnico" (1997: 61).

Regularmente el concepto de "indígena boliviano o quechua" es utilizado por San Román para referirse a situaciones negativas donde el indígena se muestra hostil hacia los expedicionarios, quienes vienen a ser los representantes más inmediatos del proyecto expansionista y modernizador de Chile en estas tierras. Tras un conflicto con un indígena atacameño que se negaba a venderles una mula, San Román advierte que:

"[...] escenas como la anterior se repiten a cada paso entre los indios bolivianos i el viajero que los trata conforme a maneras i procedimientos a que no están habituados" (San Román 1896: 245).

En el nivel más bajo de la estratificación socio-productiva de San Pedro de Atacama se encontraban quienes no poseían tierras ni animales y que se ocupaban en el rubro agrícola como segadores y jornaleros. Esa mano de obra no solo era absorbida por los grandes propietarios vinculados a las casas comerciales, sino también por medianos propietarios indígenas que contrataban temporeros, específicamente para las labores de corte de la alfalfa. La labor de "hachar pastos", como se la denominaba, era bastante dura y mal remunerada, realizada por población local y también por indígenas foráneos e itinerantes. En Calama y Chiu Chiu la demanda de fuerza de trabajo agrícola se satisfacía con mano de obra local y usualmente también con el trabajo temporero de población indígena proveniente de Bolivia, la que resultaba mucho más rentable puesto que sus salarios se reducían prácticamente a la mitad de los jornales atacameños (San Román 1896:393-394).17

Para reafirmar lo anterior etnográficamente, un dirigente de Caspana perteneciente a una organización denominada Tradiciones y Costumbre de El Loa, nos menciona que:

\footnotetext{
${ }^{17}$ Esta situación en la actualidad permanece debido a la vulnerabilidad en que se encuentran sobre todo los migrantes laborales ilegales en una zona de fronteras nacionales.
} 
"[...] si acá llegaron poblaciones migrantes desde Bolivia a principios del siglo pasado 1908, uno los puede identificarlos por los apellidos, aquí en el pueblo de Caspana hay familias kunza o atacameñas y otras quechua, además hay otras migraciones de familias de Caspana a unos pueblos de Argentina, Susques, y también se les puede identificar por los apellidos".

Cabe mencionar que durante el s. XX, han existido flujos migratorios permanentes transfronterizos, constatándose en la actualidad población quechua parlante en la cuenca de el Loa Superior, particularmente en los poblados de Cupo, Toconce y Caspana. La interdigitación también se puede apreciar en Chiu Chiu con la presencia de población atacameña propietaria, aymara comerciantes y quechua provenientes de localidades de interior.

\section{$*$ Conclusiones}

Se ha argumentado, a través de la presentación y análisis, datos provenientes de fuentes secundarias etnohistóricas y primarias etnográficas, la verificación de la hipótesis que considera que en "Atacama opera un sistema interétnico a manera de una estructura social que permite el intercambio simbólico, económico, social e incluso cultural entre diferentes grupos étnicos". Aquí lo étnico adquiere relevancia pues es un conjunto de imágenes expresada en discursos sobre sí mismo y los otros. No es posible entender esta zona de frontera activa sin intercambio y migraciones entre los distintos grupos coexistentes, ya que por ellos se logra identificar:
a) Productores agrícolas y ganaderos atacameños campe- sinos del oasis de San Pedro de Atacama;
b) Pastores de Puna y/o serranías denominados collas, y;
c) Grupos quechua asentados en la cuenca del Alto Loa.

Por tanto, el propósito de este trabajo fue exponer y verificar la convivencia de larga data en el tiempo de diversos grupos con adscripciones y autoadscripciones que hacen posible la convivencia por medio del intercambio material, social e ideológico. Sin duda, la problemática étnica en el contexto chileno, "lo atacameño", se ha construido, en parte, en un marco poscolonial y de un proceso nacional, adquiriendo una dinámica de inclusión y exclusión de poblaciones, inclusive con tintes racistas pues el color de piel, el idioma de origen, su forma de compor- tamiento, sus hábitos higiénicos, laborales, etc., son los marcadores culturales que harán posible la diferenciación cultural entre atacameños, quechua y colla.

Hemos desarrollado una lectura de una sociedad fragmentada a través de un ego (atacameño) y alter (colla, quechua, boliviano y runaco). La configuración de "lo atacameño" va estableciendo una dinámica rígida de inclusión y exclusión, no sin contradicciones y paradojas en el imaginario nacional chileno.

Por una parte, este campesino propietario mestizo aculturado, el atacameño, se incorpora al proyecto nacional chileno. Si bien se mantienen prácticas religiosas propias del sincretismo andino, es clave alejarse de los estilos de vida indios que son excluidos del proyecto nacional y pasan a ser definidos como "quechua" o "bolivianos". En definitiva, como extranjeros, ajenos e incluso contrarios a "lo chileno".

Las constantes migraciones han permitido la construcción de "lo atacameño" por oposición a lo "indígena boliviano", esto permitió la construcción de ciertos polos discursivos o estereotipos: sucio/limpio, moreno/blanco, quechua/castellano (incluso kunza/castellano), pastor/ agricultor, peón/patrón, llamo/caballo, acordeón/flauta, etc. Estas operaciones discursivas comienzan a definir algunos de los elementos que formarán parte de la alteridad en el imaginario nacional chileno.

Serán los propios campesinos propietarios de Atacama, quienes definirán y nominarán a sus vecinos de localidades del interior y particularmente los de el Loa como bolivianos. Por lo tanto, como extranjeros en el imaginario nacional chileno, ello tuvo claras consecuencia para los efectos de la dominación chilena o atacameña en Atacama. La utilización de la categoría "indio boliviano o quechua" viene a representar la posibilidad de superioridad cultural y racial asociado a lo chileno y moderno. Esta situación en la actualidad permanece debido a la vulnerabilidad en que se encuentran sobre todo los migrantes laborales ilegales en una zona de fronteras nacionales.

Este panorama desigual y versátil de las dinámicas económicas, productivas y sociales de la población indígena, también sus transformaciones y readaptaciones, obliga a sostener que no es posible reducirla desde un punto de 
vista analítico a una única categoría socioeconómica ${ }^{18}$, será la propia dinámica cultural, no solo interna de cada grupo, sino también las de carácter interétnico en Atacama las que configurarán un escenario que será impactado por el proceso expansivo del capital al "interior" de Antofagasta, siempre acompañado de una feroz campaña de chilenización.

Por el momento, es posible afirmar que ciertas operaciones identitarias que excluían al "indio boliviano", responden a un proceso que obedeció y obedece a la construcción de alteridad dentro de un imaginario nacional, propuesto por la élite chilena a partir de parámetros modernos clásicos. Estos imponían los criterios de unidad, homogeneidad e integridad del territorio, a partir de los cuales se autoasignaron la misión de definir, excluir y establecer sus límites simbólicos y territoriales. Desde esta perspectiva, la operación discursiva de alteridad ego/alter, atacameño/boliviano o quechua, fue funcional a la consolidación del proyecto modernizador chileno impulsado por la oligarquía liberal de fines del s. XIX y comienzos del XX. Proyecto que hoy permanece vigente en el imaginario atacameño y chi-

${ }^{18}$ Distribución estratificada de la propiedad de la tierra, la redefinición productiva y laboral de aquellos sectores antes vinculados a la arriería mulera, el desarrollo del trabajo asalariado en el rubro agropecuario y minero, y la circulación y eventual radicación de población indígena y mestiza proveniente de otras regiones (especialmente de Argentina y Bolivia). leno en una especie de campo o estructura social de la diferencia cultural.

Recapitulando, proponemos que el reconocimiento legal de la etnia atacameña en 1994 es el reconocimiento de un sujeto estable, con cualidades claramente definibles y abordables por las políticas públicas y privadas. La inclusión de los atacameños se debe a su condición histórica de integración y a su posición hegemónica sobre grupos vecinos; estos últimos al optar por la adscripción atacameña, ganan visibilidad y reconocimiento. El proceso de etnización de los atacameños facilita la integración e identifica claramente lo chileno como contrario a lo extranjero. Aquí estamos visibilizando una estructura social que sostuvo y sostiene fuertes procesos de inclusión y exclusión, la que opera como un campo que dará fisonomía a corporaciones socioculturales denominadas hoy etnias.

Agradecimientos Este trabajo ha sido elaborado en el marco de la Beca Doctoral ALBAN 2007-2010 otorgada por la Comunidad Europea y la Universidad Libre de Berlín. Además, agradecemos a un grupo de colegas por sus comentarios y sugerencias en miras del perfeccionamiento de este escrito. Asimismo, agradecemos a las autoridades y comuneros; alcaldesa Sandra Berna, Mirta Solís, Félix Ramos, Margarita Chocobar, Carmela Armella, Rubén Reyes, Sótero Armella, Eva Siárez, Ramón Torres y Gabriel González.

\section{* Referencias citadas}

ABERCROMBIE, T., 1991. Articulación doble y etnogénesis. En Reproducción y transformación de las sociedades andinas. Siglos XVI-XX, S. Moreno y F. Salomón (Eds.), pp. 197-212. Abya-Yala, Quito.

2006. Caminos de la memoria y del poder, etnografía e historia en una comunidad. SIERPE, La Paz.

ALBÓ, X., 2000. Aymaras entre Bolivia, Perú y Chile. Estudios Atacameños 19: 43-73.

ALDUNATE, C., J. BERENGUER y V. CASTRO, 1981. La función de las chullpas en Likán. Actas del VIII Congreso Nacional de Arqueología Chilena, pp. 129-174. Ediciones Kultrún, Santiago.

ANDERSON, B., 1993. Comunidades imaginadas: Reflexiones sobre el origen y la difusión del nacionalismo. Fondo de Cultura Económica, México D.F.
AYALA, P., 2006. Relaciones y discursos entre atacameños, arqueólogos y Estado en Atacama (II Región, norte de Chile). Tesis para optar al grado de Magíster en Antropología, Universidad Católica del Norte y Universidad de Tarapacá, San Pedro de Atacama.

BARROS, A., 2008. Identidades y propiedad: Transiciones territoriales en el s. XIX atacameño. Estudios Atacameños, Arqueología y Antropología Surandinas 35: 119-139.

BARTH, F., 1976 [1970]. Los grupos étnicos y sus fronteras. Fondo de Cultura Económica, México D.F.

BARTOLOMÉ, M., 1979. Conciencia étnica y autogestión indígena. Indianidad y descolonización en América. Editorial Nueva Imagen, México D.F. 
2000. Etnias y naciones: La construcción civilizatoria en América Latina. En Los retos de la etnicidad en los Estados nación del s. XXI, L. Reina (Ed.). CIESAS-INIPORRUA, México D.F.

2004. Procesos interculturales: Antropología política del pluralismo cultural en América Latina. Siglo XXI, México D.F.

BERENGUER, J., C. ALDUNATE y V. CASTRO, 1984. Orientación orográfica de las chullpas en Likán: La importancia de los cerros en la fase Toconce. Actas del $44^{\circ}$ Congreso Internacional de Americanistas, Simposio Culturas Atacameñas: 175-220. Universidad del Norte, Antofagasta.

BERTRAND, A., 1885. Memoria sobre las cordilleras del Desierto de Atacama y rejiones limítrofes. Imprenta y Litografía Antonio J. Escobar y Cía., Santiago.

BOCCARA, G., 1999. Etnogénesis mapuche: Resistencia y reestructuración entre los indígenas del centro-sur de Chile (s. XVIXVIII). Hispanic American Historical Review 79: 425-461.

2002. Construyendo identidades desde el poder: Los indios en los discursos republicanos de inicios del s. XIX. En Mestizaje, identidades y Poder en las Américas, G. Boccara (Ed.), pp. 27-46. Abya-Yala-Instituto Francés de Estudios Andinos (IFEA), Quito.

CARDOSO, R., 1964. O indio e o mundo dos brancos. Brasil: Universidade de Brasilia, Brasilia.

1992. Etnicidad y estructura social. Colección M. O. de Mendizábal, CIESAS, México D.F.

CASTRO, V., 1997. Pastoreo en humedales de tierras altas en los Andes del norte de Chile: persistencia y cambios. Actas del Segundo Congreso Chileno de Antropología, vol. 2: 559-566. Colegio de Antropólogos, Santiago.

1998. La dinámica de las identidades en la subregión del río Salado, provincia de El Loa, II región. I Encuentro Nacional Interinstitucional de Investigadores de Identidades Culturales, M. Dannemann (Ed.), pp. 5-50. Universidad de Chile, Santiago.

2000. Llameros de puna salada en los Andes del norte de Chile. En Pastoreo altoandino. Realidad, sacralidad y posibilidades, J. Flores Ochoa y Y. Kobayashi (Eds.), pp. 85-109. Plural/MUSEF, La Paz.

2001. Atacama en el tiempo, territorios, identidades, lenguas (provincia El Loa, II Región). Anales de la Universidad de Chile VI serie: 13 .

CASTRO, V. y J. L. MARTÍNEZ, 1996. Poblaciones indígenas de Atacama. En Etnografía. Sociedades indígenas contemporáneas y su ideología, J. Hidalgo, V. Schiappacasse, H. Niemeyer, C. Aldunate y P. Mege (Eds.), pp. 69-110. Editorial Andrés Bello, Santiago.

COnTRERAS, E., 2005. Pueblos transfronterizos en la Puna de Atacama: Conectividad de redes en el país más allá de las nubes. Tesis para optar al título de Antropólogo Social, Departamento de Antropología, Universidad de Chile. Santiago.
CRÉQUI-MONFORT, G. y E. SÉNÉCHAL, 1904. Rapport sur une mission scientifique en Amérique du Sud Bolivie, République Argentine, Chili, Pérou. Imprimérie Nationale, París.

DEGREGORI, C. y G. PORTOCARRERO, 2004. Cultura y globalización. Red para el desarrollo de las ciencias sociales en el Perú, Lima.

DÍAZ-POLANCO, H., 2006. Elogio de la diversidad: Globalización, multiculturalismo y etnofagia. Siglo XXI, México D.F.

D'ORBIGNY, A., 1839. L'homme américain (de l'Amérique méridionale), considéré sous ses rapports physiologiques et moraux. Chez F-G. Levrault, París.

GARRIDO, C., 2001. El pastoreo trashumante de las comunidades collas de la III Región. Documento preparado para CONADI-Sub Dirección Norte, Iquique.

GÖBEL, B., 2002. La arquitectura del pastoreo: Uso del espacio y sistema de asentamientos en la Puna de Atacama (Susques). Estudios Atacameños 23: 1-24.

GONZÁLEZ, S., 2002. Chilenizando a Tunupa. La escuela pública en el Tarapacá andino 1880-1990. DIBAM, Santiago.

GUNDERMANN, H., 1998. Pastoralismo andino y transformaciones sociales en el norte de Chile. Estudios Atacameños 16: 293-319.

2002. Los atacameños del s. XIX y XX, una antropología histórica regional. Documento de Trabajo CVHNT/GTPIN/2002/051, pp. 127-156, San Pedro de Atacama.

HOBSBAWM, E., 2002 [1983]. La invención de la tradición. En La Invención de la tradición, E. Hobsbawm y T. Ranger (Eds.), pp. 7-21. Editorial Crítica, Barcelona.

HOPENHAYN, M., 2005. América Latina, desigualy descentrada. Grupo Editorial Norma, Buenos Aires.

LATCHAM, R., 1938. Arqueología de la región atacameña. Imprenta Universidad de Chile, Santiago.

LEHNERT, R., 1981. Préstamos del quechua y castellano a la lengua kunza. Scripta Ethnologica VI: 99-101.

1991. Préstamos del runa-simi a la lengua kunza. Hombre y Desierto 5:30-48.

MARTÍNEZ, J. L., 1985. Adaptación y cambio en los atacameños. Los inicios del período Colonial, s. XVI y XVII. Andes 3:19-34.

1990. Interetnicidad y complementariedad en el Altiplano Meridional. Andes 1: 11-30.

1994. Relaciones y negociaciones entre las sociedades indígenas de la región atacameña, el Estado y la sociedad chilena. Siglos XIX y XX. Proposiciones 24: 201-207.

MERCADO, J., 2007. Los inicios de la chilenización en Atacama: Una aproximación a las discursividades sobre el indio atacameño' durante la posguerra del Pacífico (1885-1910). Revista de 
Cooperación Descentralizada, Internacionalización de las Regiones y Paradiplomacia. www.parinas.cl.

MOLINA, R., 2007a. Relaciones transfronterizas entre atacameños $y$ collas en la frontera norte chilena-Argentina. La desintegración de espacios y articulaciones tradicionales indígenas. Institut-Gouvernance, París.

2007b. Viajes, arriería, intercambios y articulaciones, entre la Puna y el Desierto de Atacama: Relatos desde Antofagasta de la Sierra, Antofalla, Fiámbala y Copiapó. VII Congreso Argentino Chileno de Estudios Históricos e Integración Cultural. Universidad de Salta, Salta.

MOORE, T., 1877. La lengua atacameña. 2nd International Congress of mericanists. Session 2, Part. 2: 44-54, Luxemburgo.

MOSTNY, G., 1954. Peine Un pueblo atacameño. Editorial Universitaria, Santiago.

MORALES, H., 1997. Pastores trashumantes al fin del mundo. Un enfoque cultural de la tecnología: En una comunidad andina de pastores. Memoria para optar al título de Antropólogo Social, Departamento de Antropología, Facultad de Ciencias Sociales, Universidad de Chile. Santiago.

2010. Etnopolítica en Atacama. Laberintos de la etnicidad atacameña. Freie Universitât Berlin, Berlín.

MURRA, J., 1972. El control vertical de un máximo de pisos ecológicos en la economía de las sociedades andinas. Universidad Emilio Valdizán, Lima.

NÚÑEZ, L., 1992. Cultura y conflicto en los oasis de San Pedro de Atacama. Editorial Universitaria, Santiago.

NÚÑEZ, M., 2002. Transformaciones culturales en Toconao por impacto de empresas mineras: Un estudio de caso en el norte de Chile. Memoria para optar al grado de Magíster en Antropología y Desarrollo, Facultad de Ciencias Sociales, Universidad de Chile, Santiago.

ORELLANA, M., 2006. Historia de la arqueología en Chile (1842-1990). Colección Ciencias Sociales, Universidad de Chile, Santiago.

OYARZÚN, A., 1935. Instrumentos de caza y guerra en los atacameños. Actas del 26 Congreso Internacional Americanista, vol. 1: 217229.

OVIEDO, F., 1902 [1557]. Historia general y natural de las indias, islas y tierra firme del mar Océano. Colección de Historiadores de Chile, vol. XXVII. Santiago.

PHILIPPI, R., 1860. Viaje al Desierto de Atacama hecho de orden del Gobierno de Chile en el verano 1853-1854. Librería Eduardo Antón, Halle, Sajonia.

RIVERA, F., 1994. La interrelación sociedad mayor/etnia atacameña en torno a la apropiación social de los recursos en San Pedro de Atacama. Memoria para optar al título de Antropólogo Social. Universidad de Chile, Santiago.
SÁNCHEZ, G., 1998. Multilingüismo en el área de San Pedro de Atacama. Lenguas aborígenes atestiguadas por la fitonimia del área de San Pedro de Atacama, Estudios Atacameños 16: 171-180.

SCHULLER, R., 1908. Estudios de la lengua de los indios. Lickan-Antay (atacameños)-Calchaquí. Imprenta Cervantes, Santiago.

SAN ROMÁN, F., 1890. La lengua kunza de los naturales de Atacama. Imprenta Gutenberg, Santiago.

1896. Desierto $i$ cordilleras de Atacama. Imprenta Nacional, Santiago.

SANHUEZA, C. 1992. Estrategias readaptativas en Atacama: La arriería mulera colonial. En Etnicidad, economía y simbolismo en los Andes, S. Arze, R. Barragán, L. Escobari y X. Medinacelli (Eds.), pp. 363-385. HISBOL-Instituto Francés de Estudios Andinos (IFEA)-Sociedad Boliviana de Historia (SBH)-ASUR. La Paz.

SANHUEZA, C. y H. GUNDERMANN, 2007. Estado, expansión capitalista y sujetos sociales en Atacama (1879-1928). Estudios Atacameños, Arqueología y Antropología Surandinas 34: 113-136.

SCHIAPPACASSE, V., V. CASTRO y H. NIEMEYER, 1989. Los Desarrollos Regionales en el Norte Grande (1000 a 1400 DC). En Culturas de Chile. Prehistoria, desde sus orígenes hasta los albores de la Conquista, J. Hidalgo, V. Schiappacasse, H. Niemeyer, C. Aldunate e I. Solimano (Eds.), pp. 181-226. Editorial Andrés Bello, Santiago.

STAVENHAGEN, R, 1992. La cuestión étnica: Algunos problemas teórico metodológicos. Estudios Sociológicos X(28): 23-34.

2000. Conflicto étnico y Estado nacional. United Nations Research Institute for Social Development-Siglo XXI, México D.F. 2001. La cuestión étnica. El Colegio de México, México D.F.

TSCHUDI, J., 1869. Reissen Durch Südamerika, vol. 5 Leipzig.

UHLE, M., 1912. Los indios atacameños. Biblioteca Iberoamericana. Referencia N-0035 W 107, Berlín.

URIBE, M. y L. ADAN, 2003. Arqueología, poblaciones originarias y patrimonio cultural en el Desierto de Atacama. Chungara, Revista de Antropología Chilena 35(2): 295-304.

VAÏSSE, E., 1894. Artículo publicado en el diario El Industrial, Antofagasta, 21 de junio.

VAÏSSE, E., F. HOYOS y A. ECHEVERRÍA, 1896. Glosario de la lengua atacameña. Imprenta Cervantes, Santiago.

VALENZUELA, J., 1999. Reflexiones sobre el presente y futuro del paisaje político chileno a la luz de su pasado. Respuesta a Eugenio Tironi y Felipe Agüero. Estudios Públicos 75: 273-290.

ZIZEK, S., 1998. Multiculturalismo o la lógica cultural del capitalismo multinacional. Paidós, Buenos Aires.

ZIZEK, S. y F. JAMESON, 2001. Estudios culturales. Reflexiones sobre el multiculturalismo. Paidós, Buenos Aires. 